\title{
Perencanaan Pengelolaan Kawasan Konservasi Berbasis Pemberdayaan Masyarakat (Studi pada Balai Taman Nasional Gunung Merapi Propinsi Daerah Istimewa Yogyakarta)
}

\author{
Andrian Susanto ${ }^{a^{*}}$ \\ ${ }^{a}$ Balai Taman Nasional Manupeu Tanah Daru, Pulau Sumba, Nusa Tenggara Timur, Indonesia
}

\section{INFORMASI ARTIKEL \\ Article history: \\ Dikirim tanggal: 01 Februari 2016 \\ Revisi pertama tanggal: 12 Februari 2016 \\ Diterima tanggal: 31 Mei 2016 \\ Tersedia online tanggal 18 September 2016}

Keywords: planning, npmm, community development

\begin{abstract}
Referring to the vision of the Ministry of Forestry, vision NPMM Office is Becoming National Park Yang Settled in Managing Human Volcano Dynamic Based Participation of Parties, in which the management of NPMM takes the role of the participation of the parties, especially communities in creating plans that are participatory and collaborative, one size for assess the success of the performance can be seen from how NPMM Office planned community development programs in the villages around NPMM. The focus of this study is to determine how NPMM management planning related to community development activities. Results of this study concluded that the planning of community-based management of NPMM is not likely to procedural but substantive aspects already accommodated, already apply the principle of sustainable development. In the planning of community development activities have also been pursued in a participatory and collaborative, though still within the framework of fulfilling the social responsibility of the organization or the policy direction of the Ministry of Environment and Forestry.
\end{abstract}

\section{INTISARI}

Mengacu dari visi Kementerian Kehutanan, visi BTNGM adalah Menjadi Taman Nasional Yang Mantap Dalam Mengelola Ekosistem Volcano Yang Dinamis Berbasis Partisipasi Para Pihak, dimana dalam pengelolaan TNGM dibutuhkan peran partisipasi para pihak terutama masyarakat dalam menciptakan perencanaan yang bersifat partisipatif serta kolaboratif, maka salah satu ukuran untuk menilai keberhasilan kinerjanya dapat dilihat dari bagaimana BTNGM merencanakan program pemberdayaan masyarakat di desa sekitar TNGM. Fokus penelitian ini adalah untuk mengetahui bagaimana perencanaan pengelolaan TNGM terkait kegiatan pemberdayaan masyarakat. Hasil dari penelitian ini menyimpulkan bahwa perencanaan pengelolaan TNGM berbasis pemberdayaan masyarakat sudah tidak cenderung prosedural saja tetapi aspek substantif sudah diakomodasi, sudah menerapkan prinsip pembangunan berkelanjutan. Selain itu, dalam perencanaan kegiatan pemberdayaan masyarakat juga telah diupayakan secara partisipatif dan kolaboratif, walaupun masih dalam kerangka memenuhi tanggung jawab sosial organisasi atau arahan kebijakan Kementerian Lingkungan Hidup dan Kehutanan.

2016 FIA UB. All rights reserved.

\footnotetext{
* Corresponding author. Tel.: +62-812-1532-5576; e-mail: andrians1985@ gmail.com
} 


\section{Pendahuluan}

Taman Nasional Gunung Merapi merupakan kawasan konservasi yang memiliki beragam jenis flora dan fauna serta segala keunikannya merupakan salah satu kekayaan alam yang dapat dijadikan andalan dalam menjamin kelangsungan hidup manusia pada umumnya dan masyarakat sekitar TN Gunung Merapi pada khususnya. Keberadaan masyarakat merupakan bagian yang tidak terpisahkan dari kawasan konservasi. Kebutuhan akan kawasan konservasi seringkali menjadi perdebatan, dimana keberadaan mereka diartikan sebagai tekanan terhadap keberadaan dan kelestarian kawasan konservasi.

Masyarakat sekitar Merapi memanfaatkan kawasan sebagai sumber utama ekonomi sebagai sumber rumput untuk pakan ternak, sebagian kayu untuk kayu bakar dan bahan pembuatan arang serta penambangan pasir yang melibatkan pelaku dari luar daerah. Masyarakat memiliki potensi untuk dilibatkan dalam menjaga dan melindungi kawasan TN Gunung Merapi. Oleh sebab itu diperlukan strategi dalam membangun dukungan bagi kelestarian TN Gunung Merapi dengan tetap memberikan hak pemanfaatan kawasan terbatas kepada masyarakat sesuai zona-zona yang telah ditetapkan peruntukannya. Disamping itu, pengetahuan masyarakat mengenai nilai dan fungsi penting kawasan perlu ditingkatkan pada akhirnya mereka mau terlibat dalam upaya perlindungan di kawasan TNGM.

Pemberdayaan masyarakat sekitar hutan merupakan kebijakan prioritas Kementerian Kehutanan. Tujuan yang ingin dicapai dari pemberdayaan masyarakat menurut Sulistiyani (2004) adalah untuk membentuk individu dan masyarakat menjadi mandiri. Tentunya dalam pemberdayaan masyarakat direncanakan suatu model pengelolaan masyarakat yang komprehensif dan berbasis ekosistem berkelanjutan. Sehubungan dengan pendapat Abe (2002) yang membuat perubahan untuk mencapai kondisi yang lebih baik dan lebih bermakna, tahap proses dimulai dari tahap perencanaan, maka tahap berikutnya pelaksanaan dan evaluasi. Dengan demikian perencanaan adalah salah satu langkah penting dalam pelaksanaan pembangunan dalam hal ini untuk memberdayakan masyarakat.

Menilik pada permasalahan dan terkait dengan perencanaan pembangunan, rumusan masalah penelitian ini adalah: 1) Bagaimanakah proses perencanaan pengelolaan TN Gunung Merapi berbasis pemberdayaan masyarakat?; dan 2) Bagaimana peran dan interaksi stakeholders dalam proses perencanaan pengelolaan TN Gunung Merapi berbasis pemberdayaan masyarakat?. Sementara itu, tujuan dari penelitian ini adalah: 1) Mendeskripsikan dan menganalisis proses perencanaan pengelolaan TN Gunung Merapi berbasis pemberdayaan masyarakat; dan 2) Mendeskripsikan dan menganalisis peran dan interaksi stakeholders dalam proses perencanaan pengelolaan TN Gunung Merapi berbasis pemberdayaan masyarakat.

\section{Teori}

\section{Pembangunan Berkelanjutan}

Konsep sustainable development (pembangunan berkelanjutan) awalnya muncul diperkenalkan oleh The World Commission on Environment and Development. Komisi tersebut memaknai pembangunan berkelanjutan adalah suatu daya untuk memenuhi kebutuhan generasi sekarang dengan tanpa mengorbankan kebutuhan generasi yang akan datang.

Pembangunan berkelanjutan mengakui kebutuhan untuk memproduksi sumber pemenuhan kebutuhan manusia. Kesuksesannya bergantung dari masukan para pengambil kebijakan dan termasuk para individu dari kalangan bawah. Pembangunan berkelanjutan tersebut mengombinasikan manajemen sumber daya dengan produksi, ketersediaan pekerjaan yang cukup, ketahanan pangan, keterbukaan akses produk, distribusi peluang dan pemerataan sumber-sumber antara gender dari antar generasi. Sebagaimana pendapat dari Dwivedi dan Henderson (1999) mengenai pembangunan berkelanjutan sebagai berikut: "Sustainable development model is based on long-term thinking and conservation of nature's finite resources. In numerous countries, the existing political organizations still view the environment as resources to be used and exploited for private gain. In the past, many development theorist ignored the impact of degradation of the environment on the future".

Dari uraian diatas menjelaskan bahwa konsep pembangunan harus berfokus pada kebutuhan dasar manusia dan kelestarian lingkungan agar pembangunan berkelanjutan dapat dipertahankan. Manusia adalah makhluk yang hidup pada lingkungan, kualitas lingkungan yang buruk akan menyebabkan kualitas hidup manusia menurun.

\section{Perencanaan Pembangunan}

Menurut George R. Terry dalam Riyadi dan Bratakusumah (2004) perencanaan adalah upaya untuk memilih dan menghubungkan fakta-fakta dan membuat serta menggunakan asumsi-asumsi mengenai masa yang akan datang dengan jalan menggambarkan dan merumuskan kegiatan-kegiatan yang diperlukan untuk mencapai hasil yang diinginkan. Perencanaan yang baik seharusnya mempertimbangkan kedua teori perencanaan tersebut, baik teori prosedural maupun teori substantif karena perencanaan yang baik tidak mungkin dilakukan dengan mengabaikan esensi dan persoalan yang dibahas. 
Oleh karena itu, baik teori prosedural maupun teori substantif saling melengkapi. Diharapkan kedua teori tersebut akan membentuk suatu kolaborasi yang oleh Faludi (1973) disebut sebagai perencanaan efektif.

Perencanaan menurut Kunarjo (2002) dapat disusun berdasarkan beberapa kriteria, antara lain menurut jangka waktu, menurut ruang lingkup atau tingkat keluwesan. Menyangkut jangka waktu, ada rencana jangka panjang, jangka menengah dan jangka pendek. Perencanaan jangka panjang, menurut Tjokroamidjojo (1994) mempunyai sifat dua macam: pertama, merupakan proyeksi keadaan masa depan dengan jangka waktu yang cukup panjang, kedua, perencanaan kebijaksanaan yang dimaksudkan untuk mencapai tujuan-tujuan perkembangan dalam masyarakat yang bersifat fundamental dan struktural. Sedangkan perencanaan jangka menengah menurut Kunarjo (2002) biasanya dikaitkan dengan kebutuhan secara politis berdasarkan jangka waktu jabatan para penguasa. Adapun perencanaan jangka pendek dapat dikatakan sebagai perencanaan operasional tahunan yang mempunyai kurun waktu pendek yaitu satu tahun.

Menurut Wahyudi (2006) proses perencanaan pembangunan daerah merupakan:

a. Proses politik. Pemilihan langsung kepala daerah akan menghasilkan rencana pembangunan hasil proses politik khususnya penjabaran visi dan misi dalam RPJM.

b. Proses teknokratik. Perencanaan yang dilakukan oleh perencana profesional atau oleh lembaga/unit organisasi yang secara fungsional melakukan perencanaan khususnya dalam pemantapan peran, fungsi dan kompetensi lembaga perencana.

c. Proses partisipatif. Perencanaan yang melibatkan masyarakat (stakeholders) antara lain melalui pelaksanaan musyawarah perencanaan pembangunan.

d. Proses Bottom-up dan Top-down. Perencanaan yang aliran prosesnya berlangsung dari atas ke bawah atau dari bawah ke atas dalam hirarki pemerintahan.

Menurut Kuncoro (2004), sistem perencanaan pembangunan dengan menggunakan pendekatan topdown planning dan bottom-up planning akan menjamin adanya keseimbangan-keseimbangan antara prioritas nasional dengan aspirasi lokal dalam perencanaan pembangunan daerah.

\section{Pemberdayaan Masyarakat}

Suhendra (2006) mengartikan pemberdayaan sebagai suatu kegiatan yang berkesinambungan, dinamis, secara sinergis mendorong keterlibatan semua potensi yang ada secara evolutif. Sedangkan pemberdayaan masyarakat dapat diartikan sebagai masyarakat diberi kuasa, dalam upaya untuk menyebarkan kekuasaan, melalui pemberdayaan masyarakat, organisasi, agar mampu menguasai atau berkuasa atas kehidupannya untuk semua aspek kehidupan politik, ekonomi, pendidikan, kesehatan, pengelolaan lingkungan dan sebagainya. Memberdayakan masyarakat menurut Kartasamita (1996) adalah upaya untuk meningkatkan harkat dan martabat lapisan masyarakat yang dalam kondisi sekarang tidak mampu untuk melepaskan diri dari perangkap kemiskinan dan keterbelakangan. Dengan kata lain memberdayakan adalah memampukan dan memandirikan masyarakat. Sejalan dengan Kartasamita, Sunartiningsih lebih melihat pemberdayaan sebagai cara untuk meningkatkan kemampuan masyarakat melalui peningkatan kemampuan lembaga-lembaga yang ada di masyarakat.

Sulistiyani (2004) mengatakan tujuan pemberdayaan adalah untuk membentuk individu dan masyarakat menjadi mandiri. Kemandirian tersebut meliputi kemandirian berpikir, bertindak dan mengendalikan apa yang mereka pikirkan. Berkaitan dengan konsep pemberdayaan tersebut, Winarni dalam Sulistiyani (2004), mengungkapkan, inti dari pemberdayaan adalah meliputi tiga hal, yaitu pengembangan (enabling), memperkuat potensi atau daya (empowering), terciptanya kemandirian. Hal ini mengindikasikan pemberdayaan tersebut tidak hanya untuk masyarakat yang tidak memiliki kemampuan tetapi juga untuk masyarakat yang memiliki kemampuan yang masih sedikit untuk dikembangkan agar bisa mandiri.

\section{Metode Penelitian}

Penelitian ini dilakukan dengan menggunakan metode deskriptif kualitatif. Adapun teknik pengumpulan data melalui Wawancara, observasi dan studi dokumen. Analisis data menggunakan model interaktif Milles, Huberman dan Saldana. Menurut Miles, Huberman dan Saldana (2014) terdapat empat tahapan yang harus dilakukan yaitu: pengumpulan data, kondensasi data, penyajian data dan menarik kesimpulan/ verifikasi. Sugiyono (2008) menjelaskan bahwa analisis data merupakan proses mencari dan menyusun sistematis data yang diperoleh dari hasil wawancara, observasi dan dokumentasi dengan cara mengorganisasikan data ke dalam kategori, menjabarkan ke dalam unit-unit, melakukan sintesa, menyusun ke dalam pola, memilih mana yang penting dan yang akan dipelajari dan membuat kesimpulan sehingga mudah dipahami oleh diri sendiri maupun orang lain.

\section{Hasil dan Pembahasan}

Balai TN Gunung Merapi (BTNGM) adalah Unit Pelaksana Teknis Kementerian Lingkungan Hidup dan Kehutanan (KLHK) dibawah Direktorat Jenderal Konservasi Sumber Daya Alam dan Ekosistem (Dirjen 
KSDA\&E) bertugas mengelola TN Gunung Merapi. Untuk mencapai tujuannya, BTNGM dimulai dengan melakukan penyusunan dokumen perencanaan. Dalam sebuah dokumen perencanaan berisi tentang visi, misi, program dan kegiatan yang digunakan sebagai acuan dalam pengelolaan TN Gunung Merapi dalam jangka waktu tertentu. Perencanaan publik menurut Syafiie, et al. (2006) berarti pembuatan penetapan melalui proses pengambilan keputusan mengenai kegiatan publik dan akan dilaksanakan untuk jangka waktu tertentu di masa depan secara terarah sesuai dengan tujuan yang ditetapkan bersama. Dalam melaksanakan kegiatan, dasar yang dijadikan acuan adalah Rencana Pengelolaan Taman Nasional (RPTN) untuk rencana jangka panjang dan Rencana Strategis untuk jangka menengah serta Rencana Kerja Tahunan yang merupakan rencana jangka pendek.

Kegiatan dan program yang direncanakan maupun telah dilaksanakan oleh BTNGM tentunya bermaksud untuk mencapai visi dan misi. Mengacu pada visi KLHK, visi BTNMT adalah "Menjadi Taman Nasional Yang Mantap Dalam Mengelola Ekosistem Volcano Yang Dinamis Berbasis Partisipasi Para Pihak", maka salah satu ukuran untuk menilai keberhasilan kinerjanya dapat dilihat dari bagaimana BTNGM merencanakan program dengan mengikutsertakan para pihak salah satunya program pemberdayaan masyarakat. UU Kehutanan dan dalam visi KLHK menyiratkan mandat bahwasanya dalam pengelolaan hutan dalam hal ini Taman Nasional harus mempertimbangkan aspek kesejahteraan masyarakat sekitar hutan. Namun tanggung jawab ini biasanya masih bersifat normatif dalam hal ini tergantung pada itikad baik dari otoritas Taman Nasional. Hal tersebut sesuai dengan apa yang ditunjukkan Setyowati (2008) yang menyatakan bahwa ancaman terhadap kawasan konservasi sangat terkait dengan pengelolaan dan pemeliharaan kawasan hutan lindung karena dinilai kurang partisipatif, transparan, bertanggung jawab dan akuntabel. Skema dari pengelolaan ini adalah kurang mengakomodasinya aspirasi masyarakat dan stakeholders terkait, sehingga adanya suatu keengganan stakeholders untuk berbagi tanggungjawab untuk melindungi kawasan konservasi.

\section{Identifikasi Kegiatan Pemberdayaan dalam Perencanaan Pengelolaan TNGM}

Dari hasil studi dokumen dan wawancara peneliti menemukan beberapa hal sebagai berikut:

a) Balai TN Gunung Merapi telah memiliki dokumen yang terkait dengan perencanaan yang didalamnya termuat kegiatan pemberdayaan masyarakat yang disusun berdasarkan jangka baik periode jangka panjang, jangka menengah dan jangka pendek. Kunarjo (2002) menyampaikan bahwa perencanaan disusun menurut kriteria diantaranya menurut jangka waktu. Beberapa dokumen yang terkait dengan perencanaan kegiatan pemberdayaan masyarakat TN Gunung Merapi, antara lain:

- Rencana Pengelolaan Taman Nasional

BTNGM telah memiliki dokumen RPTN Gunung Merapi periode 2015-2024 yang merupakan review dari RPTN Gunung Merapi periode 20052024. Dasar dari dilakukannya review dokumen perencanaan ini adalah Peraturan Pemerintah No. 28 tahun 2011 tentang Pengelolaan Kawasan Suaka Alam dan Kawasan Pelestarian Alam (KSA/KPA), menjelaskan bahwa setiap kawasan konservasi wajib memiliki dokumen perencanaan, yang terdiri dari dokumen Rencana Pengelolaan Jangka Panjang berdurasi 10 tahun, dan Rencana Pengelolaan Jangka Pendek yang berdurasi 1 tahun. Selain itu terjadinya dinamika perubahan lingkungan yang diakibatkan karena erupsi Gunung Merapi Tahun 2010.

Dari visi dan misi yang ada dalam dokumen RPTN Gunung Merapi lebih lanjut dituangkan ke dalam 19 rencana aksi. Kegiatan-kegiatan yang direncanakan diharapkan mempunyai gambaran dan rumusan untuk mencapai hasil yang diinginkan. Hal ini sesuai dengan kutipan dari Riyadi dan Bratakusumah (2004) tentang pengertian perencanaan dari George R. Terry yang menyatakan perencanaan adalah upaya untuk memilih dan menghubungkan fakta-fakta dan membuat serta menggunakan asumsiasumsi mengenai masa yang akan datang dengan jalan menggambarkan dan merumuskan kegiatan-kegiatan yang diperlukan untuk mencapai hasil yang diinginkan.

- Rencana Strategis

Selain RPTN, Balai TN Gunung Merapi memiliki dokumen Rencana Strategis. Rencana strategis TN Gunung Merapi disusun berdasarkan Keputusan Direktur Jenderal PHKA Nomor SK.181/IV-Set/2010 tanggal 18 November 2010 tentang Renstra Ditjen PHKA Tahun 2010-2014, dimana dalam keputusan itu disebutkan bahwa Renstra Ditjen PHKA merupakan acuan penyusunan seluruh unit Eselon II dan UPT di lingkungan Ditjen PHKA. Akan tetapi format dan substansi Rencana Strategis (Renstra) Taman Nasional Gunung Merapi mengacu pada pedoman penyusunan Rencana Pengelolaan yang ditetapkan berdasarkan Peraturan Menteri Kehutanan Nomor P.41/Menhut-II/2008 tentang Pedoman Penyusunan Rencana Pengelolaan Kawasan Suaka Alam dan Kawasan Pelestarian Alam. Penyusunan Renstra Balai TN Gunung Merapi 20102014 diperlukan untuk lebih memacu dan fokus pada kegiatan lima tahun dan sesuai dengan kebijakan 
prioritas Kementerian Kehutanan dan Rencana Strategis Ditjen PHKA.

Ditjen PHKA dalam menyusun Renstra mengacu pada Peraturan Menteri Kehutanan Nomor: P.08/Menhut-II/2010 tentang Renstra Kemenhut 2010-2014, Undang-undang Nomor 25 tahun 2004 tentang Sistem Perencanaan Pembangunan Nasional dan Peraturan Pemerintah Nomor 20 Tahun 2004 tentang Rencana Kerja Pemerintah (RKP) mengamanatkan setiap Kementerian Lembaga Negara menyusun Rencana Strategis Kementerian/Lembaga Negara (Renstra K/L) sebagai penjabaran dari Rencana Pembangunan Jangka Menengah Nasional (RPJMN). Beberapa peraturan lain juga turut menjadi perhatian dalam menyusun Renstra Kemenhut seperti Undang-Undang Nomor 5 Tahun 1990, UndangUndang Nomor 41 Tahun 1999, Peraturan Pemerintah Nomor 44 Tahun 2004 dan Peraturan Pemerintah Nomor 6 Tahun 2007.

Sepintas RPJM dan Renstra sama, tetapi kalau dilihat dari acuan utama atau dasar penyusunan maka ada perbedaan. RPJM dokumennya lebih teknis sedangkan Renstra selain mempertimbangkan aspek teknis sebagaimana yang tertuang dalam RPJM juga memadukan dengan aspek teknis politis dari Kementerian Kehutanan melalui Direktorat Jenderal PHKA. Kunarjo (2002) mengatakan bahwa perencanaan jangka menengah biasanya dikaitkan dengan kebutuhan secara politis berdasarkan jangka waktu jabatan para penguasa. Selain itu menurut Robian dalam Arifin (2009) menyampaikan bahwa pembangunan di bidang Kehutanan merupakan bagian integral dari pembangunan nasional. Oleh karena itu, Renstra Balai TN Gunung Merapi sudah seharusnya mengacu pada perencanaan strategis yang ada di atasnya.

Penyusunan Renstra Balai TN Gunung Merapi 2010-2014 diperlukan untuk lebih memacu dan fokus pada rencana kegiatan RPTN (jangka panjang) maupun RPJM yang diacu dan disesuaikan serta sinergikan dengan kebijakan prioritas Kementerian Kehutanan dan Direktorat Jenderal PHKA.

Baik dokumen Renstra maupun RPJM keduanya mempunyai periode waktu yang sama. Tetapi dalam Renstra TN Gunung Merapi telah memuat tolok ukur keberhasilan kinerja pengelolaan TN Gunung Merapi. Kalau dilihat dari pencantuman tolak ukur keberhasilan kinerja maka dokumen renstra merupakan dokumen perencanaan jangka menengah yang lebih dijadikan acuan dalam penyusunan rencana kinerja tahunan Balai TN Gunung Merapi dari pada RPJM TN Gunung Merapi. Oleh karena itu dokumen yang dijadikan peneliti untuk menelaah perencanaan kegiatan adalah Renstra TN Gunung Merapi walaupun kedua dokumen ini dijadikan acuan untuk menyusun RKT tetapi perbedaan perencanaan kegiatan yang ada di dalamnya tidak berbeda secara signifikan khususnya perencanaan pemberdayaan masyarakat.

b) Kegiatan pemberdayaan masyarakat yang baik yang direncanakan maupun yang sudah terealisasi antara lain:

- Penguatan Kapasitas Kelembagaan

Wujud kegiatan dari penguatan kapasitas kelembagaan meliputi pembentukan kelompok masyarakat. Beberapa kelompok masyarakat yang sudah terbentuk antara lain: Sentra Penyuluh Kehutanan Pedesaan (SPKP), Masyarakat Peduli Api (MPA), Masyarakat Mitra Polhut (MMP), Pemandu Wisata, Kelompok Tani, Kader Konservasi.

- Pelatihan Peningkatan Keterampilan Masyarakat

Tujuan dilakukannya pelatihan peningkatan keterampilan adalah untuk menambah pengetahuan kepada masyarakat dalam menunjang usaha atau mata pencaharian agar tidak selalu bergantung kepada kawasan taman nasional yang identik dengan merusak kawasan.

- Peningkatan Kapasitas Kelembagaan

Peningkatan kapasitas kelembagaan ini merupakan tindak lanjut dari kegiatan pembentukan Kelompok masyarakat. Tujuan dilaksanakannya peningkatan kapasitas kelembagaan ini adalah untuk meningkatkan kapasitas kelompok masyarkat yang sudah terbentuk untuk mendukung program-program BTNGM.

- Pemberian Bantuan Peningkatan Usaha Ekonomi

Tidak hanya memberikan atau memfasilitasi pelatihan-pelatihan. Balai TN Gunung Merapi juga memberikan bantuan guna meningkatkan usaha ekonomi masyarakat. Bantuan yang diberikan ini berupa modal dan sarana dan prasarana. Mengingat masyarakat yang berada di sekitar TN Gunung Merapi memiliki keterbatasan ekonomi. Adapun jenis bantuan yang di berikan berdasarkan usulan atau rekomendasi dari pada masyarakat itu sendiri.

- Kerja sama dengan pihak luar

Dalam mejalankan pemberdayaan Balai $\mathrm{TN}$ Gunung Merapi juga telah menjalankan kerja sama dengan pihak luar. Dengan adanya kerja sama dapat membantu terutama keterbatasan anggaran yang tidak bisa mencover sepenuhnya kegiatan pemberdayaan dapat diakomodasi dari pihak luar tersebut.

- Model Desa Konservasi

Model Desa Konservasi merupakan bentuk perwujudan pemberdayaan masyarakat karena terjadinya pergeseran paradigma dari top down ke bottom up. Peran partisipatif masyarakat merupakan modal utama dalam penyusuan perencanaan dalam 
rangka pemberdayaan. Model Desa Konservasi sudah mengedepankan aspek konservasi, aspek ekonomi, aspek sosial dan budaya, serta akan menjadi contoh dalam pemberdayaan di sekitar kawasan konservasi.

Proses Perencanaan Pengelolaan TN Gunung Merapi berbasis Pemberdayaan Masyarakat

Penyusunan perencanaan pemberdayaan masyarakat di TN Gunung Merapi sudah fleksibel dimana tidak hanya mementingkan bagaimana cara tersusunnya sebuah perencanaan yang baik dan benar dalam konteks sesuai dengan peraturan perundangan dan dalam menjalankan tugas perencanaan bagi pemerintah (prosedural), akan tetapi aspek substantif juga sudah diaplikasikan. Substantif yang dimaksud dalam penelitian ini adalah dalam hal ini ilmu sosial kemasyarakatan dimana partisipasi masyarakat berperan penting dalam pemberdayaan masyarakat. Partisipasi masyarakat ini dikaji secara mendalam agar apa yang menjadi kebutuhan masyarakat dapat dimasukkan dalam bagian perencanaan pengelolaan kawasan konservasi khususnya pemberdayaan masyarakat. Bila dilihat dari perspektif Faludi (1973), perencanaan yang baik seharusnya mempertimbangkan kedua teori perencanaan, baik teori prosedural maupun teori substantif Diharapkan kedua teori tersebut akan membentuk suatu kolaborasi sehingga terwujudnya perencanaan efektif.

Konsep perencanaan pemberdayaan masyarakat melalui MDK di TN Gunung Merapi berfokus pada kebutuhan dasar manusia dan tentunya tidak mengesampingkan faktor kelestarian sumber daya alam hayati yaitu tetap lestarinya kawasan TN Gunung Merapi untuk mewujudkan pembangunan berkelanjutan. Sebagaimana kesimpulan Dwivedi dan Henderson (1999) menyatakan bahwa konsep perencanaan pembangunan berkelanjutan harus berfokus pada kebutuhan dasar manusia dan kelestarian lingkungan agar pembangunan berkelanjutan dapat dipertahankan.

Proses perencanaan pemberdayaan masyarakat di TNGM pendekatan yang digunakan adalah top down planning dan juga menggunakan pendekatan bottom up planning. Tarigan (2004) menyampaikan bahwa pada bottom up planning, institusi perencana pada level yang lebih tinggi harus menerima usulan-usulan yang diajukan oleh institusi perencana pada tingkat yang lebih rendah.

Proses perencanaan yang aliran dari atas ke bawah atau dari bawah ke atas dalam hierarki pemerintahan menurut Wahyudi (2006) adalah proses perencanaan bottom up dan top down. Proses perencanaan RPTN dan Renstra telah berjalan dengan baik dengan indikasi antara lain penyusunannya sudah diupayakan dengan partisipatif dan kolaboratif. Visi, Misi serta program dan kegiatan yang tercantum dalam dokumen tersebut relatif baik dilihat dari perspektif pemberdayaan masyarakat di
TN Gunung Merapi. Terjadi sinergitas antara proses perencanaan pemberdayaan masyarakat di TNGM dengan Musrenbang yang dilakukan pemerintah daerah meskipun belum optimal.

Dalam perencanaan pemberdayaan masyarakat di TNGM, selain didasari oleh visi KLHK dan visi BTNGM sendiri dalam rangka turut menyejahterakan masyarakat khususnya sekitar kawasan TNGM yang perencanaannya dilakukan dengan pendekatan teknokratik dan top down, maka Balai TN Gunung Merapi juga berusaha menjaring aspirasi dari masyarakat dengan pendekatan bottom up planning. Pendekatan perencanaan yang telah diupayakan oleh Balai TN Gunung Merapi menurut Wahyudi (2006) dan Tarigan (2004) merupakan proses perencanaan top down dan bottom up, yang menurut Kuncoro (2004) sistem perencanaan pembangunan dengan menggunakan pendekatan top-down planning dan bottom-up planning akan menjamin adanya keseimbangan-keseimbangan antara prioritas nasional dengan aspirasi lokal dalam perencanaan pembangunan daerah.

Adanya sinergitas antara proses perencanaan pemberdayaan masyarakat di Balai TN Gunung Merapi dengan Musrenbang yang dilakukan pemerintah daerah, walaupun belum optimal, hal ini menunjukkan bahwa proses partisipatif sudah mulai berjalan selain pihak Balai TN Gunung Merapi juga berusaha melalui Resort aktif melakukan identifikasi potensi melalui penyuluh kehutanan di lapangan untuk merencanakan kegiatan pemberdayaan masyarakat. Proses perencanaan yang melibatkan masyarakat (stakeholders) inilah yang menurut Wahyudi (2006) merupakan proses perencanaan pembangunan partisipatif. Sinergitas stakeholder dalam perencanaan pemberdayaan masyarakat menurut Riyadi dan Bratakusumah (2004) pada hakikatnya merupakan upaya untuk menyerasikan dan menyelaraskan aktivitasaktivitas pembangunan yang dilakukan oleh berbagai komponen baik pemerintah, swasta maupun masyarakat.

Peran Stakeholders dalam Proses Perencanaan Pengelolaan TN Gunung Merapi Berbasis Pemberdayaan Masyarakat

Peran stakeholders yang terlibat dalam perencanaan dan pelaksanaan pemberdayaan masyarakat sekitar TNGM diuraikan sebagai berikut:

a) Masyarakat/ kelompok masyarakat adalah sasaran kegiatan pemberdayaan sekaligus turut mengusulkan kegiatan pemberdayaan masyarakat.

b) BTNGM berperan sebagai perencana, fasilitator kegiatan dan anggaran, pembinaan/ pendampingan, monitoring dan evaluasi.

c) Pemerintah daerah, terutama desa sebagai pengarah dan pembina perencanaan keg. pemberdayaan masyarakat di desa. 
d) Dinas/ instansi terkait termasuk LSM dan Perguruan Tinggi berperan sebagai fasilitator materi dan pendampingan teknis perencanaan kegiatan pemberdayaan masyarakat

Dengan peran masing-masing stakeholders yang berbeda tersebut diatas maka hal yang terpenting adalah bagaimana terjadi koordinasi antar stakeholders agar perencanaan kegiatan pemberdayaan masyarakat dapat berjalan dengan baik. Terdapat beberapa alasan yang perlu diketahui dan dipahami dengan baik dalam hal menilai perlunya koordinasi dalam perencanaan pembangunan, yaitu (Riyadi \& Bratakusumah, 2004):

a) Koordinasi dalam perencanaan pembangunan sangat diperlukan sebagai suatu konsekuensi logis dari adanya aktivitas dan kepentingan yang berbeda;

b) Aktivitas dan kepentingan yang berbeda juga membawa konsekuensi logis terhadap adanya tanggungjawab yang secara fungsional berbeda pula;

c) Terdapat institusi, badan, lembaga yang menjalankan peran dan fungsinya masing-masing;

d) Adanya unsur sentralisasi dan desentralisasi yang dijalankan dalam proses pembangunan yang melibatkan institusi pusat maupun daerah; dan

e) Koordinasi merupakan alat sekaligus upaya untuk melakukan penyelarasan dalam proses pembangunan, sehingga akan tercipta suatu aktivitas yang harmonis, sinergi dan serasi untuk mencapai tujuan bersama.

\section{Interaksi Stakeholders dalam Proses Perencanaan Pengelolaan TN Gunung Merapi Berbasis Pemberdayaan Masyarakat}

Perencanaan kegiatan pemberdayaan masyarakat akan berjalan dengan baik apabila antar stakeholders bersinergi sesuai peran masing-masing sesuai dengan tugas pokok dan fungsinya. Interaksi antar stakeholders sudah mengarah terjadi dalam konteks kemitraan antara, BTNGM masyarakat, pemerintah daerah dan dinas/ instansi terkait termasuk LSM dan akademisi. Abe (2002) berpendapat bahwa interaksi kemitraan merupakan salah satu ciri perencanaan yang partisipatif atau demokratis yang merupakan turunan dari nilai-nilai dan prioritas guna mencapai tujuan perencanaan yaitu rasionalitas pasar dan rasionalitas sosial politik.

Interaksi kemitraan apabila dapat terwujud memiliki nilai penting karena satu pihak dengan pihak yang lain saling memposisikan sebagai mitra. Antara satu dengan yang lain tidak ada mana yang posisinya lebih tinggi dan tidak ada yang kedudukannya di bawah tetapi sejajar antara satu dan yang lain dalam menyukseskan perencanaan pelaksanaan kegiatan pemberdayaan masyarakat. Ikatan kemitraan yang dijalin dengan kelompok masyarakat desa tentunya akan mudah berlanjut menjadi kekeluargaan jika para pihak intens berinteraksi. Tentunya hal ini akan lebih memudahkan dalam rangka membangun kepercayaan untuk programprogram atau kegiatan pemberdayaan masyarakat yang dilakukan Balai TN Gunung Merapi. Dengan hubungan kemitraan antara pemerintah dan masyarakatnya, kepentingan publik yang menurut Henry (1998) merupakan pilar administrasi publik, maka responsibilitas kebijakan negara terhadap berbagai kebutuhan sosial akan lebih efektif dan efisien. Akan tetapi dari hasil penelitian tahapan interaksi antar stakeholders khususnya masyarakat belum dapat dikatakan sudah sampai pada tahap kemitraan tetapi sudah mengarah dalam konteks kemitraan. Menurut Amstein (1967) tingkat peran serta ini masih di bawah tipologi partnership (kemitraan) yaitu termasuk dalam tipologi placation (perujukan) karena masyarakat sudah mulai mempunyai beberapa pengaruh meskipun beberapa hal masih tetap ditentukan oleh pihak yang mempunyai kekuasaan.

Dengan pihak pemerintah daerah, interaksi terbangun antara lain melalui mekanisme musyawarah perencanaan pembangunan. Pihak Balai TN Gunung Merapi biasanya diundang dalam Musrenbang tingkat desa sampai tingkat kecamatan. Melalui keikutsertaan Balai TN Gunung Merapi dalam mekanisme Musrenbang telah tercipta interaksi yang mendukung terutama dalam hal perencanaan pemberdayaan masyarakat.

Berawal dari pelibatan dinas/ instansi terkait dalam perencanaan kegiatan pemberdayaan masyarakat maupun pelaksanaan kegiatan pemberdayaan masyarakat, interaksi terjadi antara Balai TN Gunung Merapi dengan dinas/ instansi terkait.

Interaksi antara stakeholders dalam perencanaan pemberdayaan masyarakat yang terjadi adalah koordinasi antara berbagai komponen dalam rangka untuk menyelaraskan kegiatan pembangunan. Riyadi dan Bratakusumah (2004) menunjukkan bahwa koordinasi dalam pembangunan pada dasarnya adalah upaya untuk menyelaraskan dan menyelaraskan kegiatan pembangunan yang dilakukan oleh berbagai komponen, termasuk sektor pemerintah, swasta dan masyarakat.

\section{Kesimpulan}

Balai TNGM telah memiliki dokumen perencanaan (RPTN, Renstra), dimana didalam dokumen tersebut termuat kegiatan-kegiatan, baik yang telah terealisasi dan akan dilaksanakan terkait dengan pemberdayaan masyarakat di TN Gunung Merapi. Terdapat 6 bentuk kegiatan yang telah dilaksanakan TN Gunung Merapi terkait dengan pemberdayaan masyarakat.

Penyusunan RPTN/ Renstra di TNGM sudah tidak cenderung prosedural saja tetapi aspek substantif sudah diakomodasi, sudah menerapkan prinsip pembangunan berkelanjutan. Menggunakan pendekatan top down dan 
bottom up planning. Selain itu, dalam perencanaan kegiatan pemberdayaan masyarakat juga telah diupayakan secara partisipatif dan kolaboratif, walaupun masih dalam kerangka memenuhi tanggung jawab sosial organisasi atau arahan kebijakan Kementerian Kehutanan. Akan tetapi mekanisme perencanaan top down dan bottom up, partisipatif serta kolaboratif relatif terjadi dengan baik. Terjadi sinergi antara proses perencanaan pemberdayaan masyarakat di BTNGM dengan Musrenbang yang dilakukan oleh pemerintah daerah meskipun belum optimal.

Stakeholders terdiri dari 4 unsur utama yaitu: (1) BTNGM merupakan perencana sekaligus fasilitator anggaran kegiatan pemberdayaan masyarakat; (2) masyarakat/ kelompok masyarakat merupakan sasaran dari kegiatan pemberdayaan sekaligus turut mengusulkan perencanaan kegiatan; (3) Pemerintah Daerah (desa) merupakan pengarah dan pembina perencanaan kegiatan pemberdayaan masyarakat; dan (4) Dinas/ instansi terkait termasuk LSM dan Perguruan Tinggi merupakan fasilitator materi dan pendamping teknis perencanaan kegiatan pemberdayaan masyarakat.

Interaksi stakeholders dalam proses perencanaan pemberdayaan masyarakat belum optimal tetapi sudah mengarah ke dalam konteks partnership (kemitraan).

\section{Daftar Pustaka}

Abe, A. (2002). Perencanaan Daerah: Memperkuat Prakarsa Rakyat dalam Otonomi Daerah. Yogyakarta: Lapera Pustaka Utama.

Arnstein, S. (1967). A Ladder of Citizen Participation. JAIP. July: 216-224.

Arifin, Y.F. (2009). Hutan sebagai Sistem Sumber Daya yang Bersifat Multiguna, Multifungsi, dan Multikepentingan". Dalam Soendjoto, Mochamad A. and Ahmad Kurnain (Eds.). Pengelolaan Sumber Daya Alam dalam Perspektif Kesejahteraan dan Keberlanjutan. Banjarmasin: Universitas Lambung Mangkurat Press.

Bahri, S. \& Algopeng, Z. (2009). Pemberdayaan Masyarakat di Sekitar Hutan Konservasi. Available at http://kerincirealitas.wordpress.com/ opini-konservasi-dan-pemberdayaan masyarakat [acessed at 03 Februari 2009)

Faludi, A. (1973). Planning Theory. England: Pergamon Press, Oxford.

Keith, H. \& Dwivedi O.P. (1999). Alternative Administration Human-Need-Centered and Sustainable: Bureaucracy and The Alternative in World Perspective. New York: ST Martin Press.

Henry, N. (1998). Administrasi Negara dan MasalahMasalah Kenegaraan. Jakarta: Rajawali.
Kartasasmita, G. (1996). Pembangunan Untuk Rakyat. Memadukann Pertumbuhan dan Pemerataan. Jakarta: PT Pustaka Cidesindo.

Kunarjo. (2002). Perencanaan dan Pengendalian Program Pembangunan. Jakarta: Penerbit Universitas Indonesia.

Kuncoro, M. (2004). Otonomi dan Pembangunan Daerah: Reformasi Perencanaan, Strategi dan Peluang. Jakarta: Penerbitan Erlanga.

Miles, M.B., Huberman, M. \& Saldana, J. (2014). Qualitative Data Analysis: A Methods Sourcebook. Sage Publication, Inc. London.

Riyadi., \& Bratakusumah, D.S. (2004). Perencanaan Pembangunan Daerah: Strategi Menggali Potensi Dalam Mewujudkan Otonomi Daerah. Jakarta: Gramedia Pustaka Utama.

Setyowati, A.B., et al. (2008). Konservasi Indonesia, Sebuah Potret Pengelolaan \& Kebijakan. Bogor: Pokja Kebijakan Konservasi, USAID and ESP.

Sugiyono. (2008). Metode Penelitian Kuantitatif, Kualitatif, Dan $R \& D$. Bandung: Alfabeta.

Suhendra, K. (2006). Peranan Birokrasi Dalam Pemberdayaan Masyarakat. Bandung: Alfabeta.

Syafiie, I.K. (2006). Ilmu Administrasi Publik. Jakarta: PT Asdi Mahasatya.

Sulistiyani, A.T. (2004). Kemitraan dan Model-Model Pemberdayaan. Yogyakarta: Gava Media.

Tarigan, R. (2004). Perencanaan Pembangunan Wilayah. Jakarta: PT. Bumi Aksara.

Tjokroamidjojo, B. (1994). Perencanaan Pembangunan. Jakarta: CV. Haji Massagung.

Wahyudi, I. (2006). Metodologi Perencanaan Partisipatif. Jakarta: Penerbit Kerjasama Malang Corruption Watch dan YAPPIKA. 